\title{
Analisando a autoria dos amores narrados nas telenovelas
}

\author{
Maria Carmem Jacob de Souza*
}

\begin{abstract}
Resumo
Como tem sido narrado os ideais amorosos da atualidade, o amor erótico romântico, nas telenovelas brasileiras? O que a experiência da autoria nas telenovelas brasileiras podem ajudar a pensar estes modos de narrar o amor? Considerando o escopo deste artigo, examinamos Mulheres Apaixonadas (TV Globo, 21 horas, fevereiro/outubro de 2003, direção geral de Ricardo Waddington) escrita por Manoel Carlos, um dos casos exemplares da experiência de autoria na televisão brasileira que faz da temática amorosa um dos seus temas de reconhecimento e consagração no campo da telenovela.
\end{abstract}

Palavras-chave: telenovelas, autoria, amor romântico

\begin{abstract}
How have they been narrated, the love ideals of actuality, the erotic romantic love, in the Brazilian "telenovelas"? How can the authorship experience in the brazilian "telenovelas" contribute to our understanding of these ways to approach and narrate love? Considering the scope of this article, we have examined "Mulheres Apaixonadas" (Passionale Women - Globo lelevision channel, 9:00 PM February to Oclober 2003 directed by Ricardo Waddinglon) written by Manoel Carlos, an example of authorship in Brazilian television. This author makes "romantic relations" one of his themes of identification and acclamation in the "telenovela" domain.
\end{abstract}

Key words: brazilian "elenovels", authorship, romantic love.

\footnotetext{
- Professora do Programa de Pós-graduação em Comunicação e Cultura Contemporâneas/ Universidade Federal da Bahia. Pesquisadora do CNPq.
} 
As telenovelas tratam do mal de amores, sendo capazes, muitas vezes, de propiciar experiências subjetivas de ilusão que acolhem, tranqüilizam, servem de referência e apoio. Recursos reflexivos (Giddens, 1993) capazes de gerar o sentimento da confiança nos indivíduos que lidam tanto com o paradoxo da existência, do desamparo primário, quanto com as tensões provenientes de uma organização social, cultural e política desigual, injusta, muitas vezes cruel.

Pressupor que as telenovelas brasileiras atuais atuam como recursos reflexivos propiciadores destas experiências de construção da auto-identidade, faz pensar sobre uma das dimensões deste processo: qual o lugar dos realizadores, principalmente os responsáveis pelo texto narrativo, como é o caso dos escritores? Sabe-se da diversidade de narrativas sobre o amor presentes nas telenovelas brasileiras. O que este artigo se propõe é examinar um dos modos de se considerar as particularidades destes modos de narrar o amor nas telenovelas. A maneira própria de narrar o amor a ser detacada será oferecida pela análise da presença do escritor-autor na instância de produção das telenovelas. Estas marcas do escritor-autor podem hoje ser localizadas em todos os horários de exibição das telenovelas da Tv Globo. Neste caso, vai-se examinar um deles, o escritor-autor Manoel Carlos, aquele que escreve telenovelas para o horário de maior importância econômica e simbólica da emissora: o que sucede o Telejornal Jornal Nacional. Considerando o escopo deste artigo, foi selecionada uma telenovela para ser examinada: Mulheres

170 Apaixonadas (TV Globo, 21 horas, fevereiro/outubro de 2003, direção geral de Ricardo Waddington)

Em Mulheres Apaixonadas o amor, tema central de Manoel Carlos, reaparece: "Mulheres apaixonadas e apaixonantes - [sobre as fotos do trio amoroso central, dois homens (Teo e César) em volta da personagem Helena] - A eterna busca pelo amor ideal e a procura pela felicidade. O Brasil inteiro assiste e se encontra em Mulheres Apaixonadas, a novela que retrata em cenas rotineiras os verdadeiros conflitos da vida moderna" (Correio da Bahia, 24 julho 2003). Nesta telenovela, mais uma vez, o escritor explorou o cotidiano familiar numa perspectiva intimista de construção dos personagens e das peripécias, sendo que neste caso, priorizou as mais diferentes manifestações amorosas e o papel que elas vem cumprindo na busca da felicidade e no afastamento dos sofrimentos.

\section{Telenovelas}

Uma definição geral de Telenovelas pode ser assim formulada: romances sentimentais produzidos para a televisão que podem ser adaptações de obras literárias, teatrais ou criações originais. Um tipo de programa de televisão caracterizado pela longa extensão, uma história contada em capítulos diários por vários meses, que pressupõe um apreciador ${ }^{1}$ ou telespectador 
disposto a acompanhar uma narrativa ficcional seriada, exibida no mesmo horário, que oferece um conjunto de temas, modos de contar as histórias, heróis e heroínas, atores e atrizes conhecidos e recorrentes. Uma tendência de explorar o drama doméstico, dando destaque ao universo familiar e feminino, tendo como um dos temas centrais, as experiencias amorosas filiais, fraternas e eróticas. O telespectador espera consumir um produto que o divirta, que o faça pensar sobre sua vida cotidiana, que o apresente a outros mundos e que o surpreenda. Antes de tudo, um produto ficcional que gere no telespectador fortes emoções sem, contudo, deixá-lo horrorizado, excessivamente angustiado e envergonhado.

A Tv Globo tem sido atualmente a emissora responsável pelo maior número de telenovelas elaboradas no Brasil e pela absorção dos melhores profissionais da área. As telenovelas significam para a Tv Globo, desde os anos setenta, a maior fonte de rentabilidade, sendo hoje, também, um importante produto de exportação.

As telenovelas da TV Globo têm sido exibidas no prime time da emissora. Não menos de três telenovelas inéditas são veiculadas após as 18 horas, com intervalo entre elas de uma hora aproximadamente. O telejornal denominado "Jornal Nacional" é exibido, desde quando foi criado, em 1969, antes da telenovela de maior audiência, que durante muitos anos foi chamada "a novela das oito". Atualmente, as telenovelas da Tv Globo são divididas em capítulos, exibidos de segunda a sábado. Cada capítulo tem a duração de 45 minutos, distribuídos, em geral, por quatro a cinco blocos que são interrompidos por intervalos comerciais. Ela é conhecida pela sua extensão: cada telenovela da Tv Globo tem hoje mais de 150 capítulos.

As telenovelas brasileiras são conhecidas ainda por uma peculiaridade: elas são escritas durante a exibição, o que implica num sistema fabril que envolve profissionais especializados, que trabalham em equipes hierarquicamente organizadas, num sistema de poder centralizado. Estes realizadores devem corresponder às exigências deste tipo de atividade: ritmo acelerado, eficiência, enorme capacidade de improvisação e criação, buscando manter a qualidade técnica e artística de um produto que deve atender o maior número de demandas dos telespectadores. Este contexto de produção exige dos escritores um empenho físico e emocional que tem levado muitos deles a trabalharem em equipe por eles coordenada, pois a responsabilidade final pela condução da narrativa e pela fidelidade e satisfação dos telespectadores tende a ser deles.

A produção de telenovelas da Tv Globo apresenta, desde os anos 70 , uma regularidade seja na escolha da ordem dos escritores das telenovelas exibidas, seja nas equipes de profissionais responsáveis pela sua elaboração, seja na qualidade audiovisual do produto ${ }^{2}$. Uma regularidade que permitiu que emergisse um telespectador conhecedor dos estilos dos escritores, que 
tem suas preferências, que espera o retorno dos escritores preferidos e que se regozija com os novos contadores de boas histórias.

Uma outra característica da telenovela concerne ao temas tratados e ao modo de enunciá-los. É conhecido no meio dos especialistas o termo a "fórmula" da telenovela que dá certo, ou seja, os temas, as situações, os personagens, os heróis e heroínas, os tipos de conflito que devem ser desenvolvidos, as soluções que devem ser exploradas, a ambiência espacial, sonora, musical e visual. Não obstante existirem estas regras básicas de condução das telenovelas é necessário reconhecer que no caso das telenovelas brasileiras, e neste caso não apenas as da Tv Globo, cada escritor em parceria com os diretores gerais, na maior parte das vezes, busca deixar o seu tom pessoal.

Vale mencionar que se firmou uma estratégia de divulgação das telenovelas da Tv Globo em que se destacam os escritores responsáveis como autores. Esta referência das telenovelas aos seus escritores-roteiristas corresponde, também, às demandas e lutas destes realizadores, e de outros profissionais da equipe realizadora, como os diretores gerais, por reconhecimento, assim como, pela busca de uma linguagem própria da televisão brasileira, em particular, de uma linguagem própria da teledramaturgia e da telenovela (Souza, 2002; 2003 e 2004).

Em suma, a equipe de profissionais responsável pela teledramaturgia na TV Globo é regida por um sistema de autoridade que define com clareza as funções dos especialistas e a distribuição de poder, de modo a garantir a realização das obras ao longo de sua exibição, num prazo determinado, com um determinado nível de qualidade e com uma determinada estimativa de rentabilidade. Isto significa que na composição e organização dos recursos narrativos, cênicos, visuais e sonoros (Gomes, 2004 e Souza, 2004) que conformam as telenovelas interfere um conjunto de exigências advindas do contexto particular de elaboração, circulação e consumo que pressupõe uma tensão permanente entre a regularidade, a forte presença da fórmula de sucesso e a novidade que também se apresenta através dos estilos pessoais dos escritores, diretores, atores e de outros especialistas envolvidos ${ }^{3}$.

Proposições que nos levaram a situar Mulheres Apaixonadas na história das telenovelas do escritor Manoel Carlos, que saiu da TV Globo em 1983, para retornar, em 1992. Depois de longa ausência no "horário das oito", retorna em 1997, escrevendo Por amor. Em seguida, escreveu Laços de família (2000) e Mulheres Apaixonadas (2003)4.

Todas as três histórias acontecem no Rio de Janeiro, num bairro da zona sul chamado Leblon, no mesmo tempo narrativo do apreciador que liga a televisão. A história narrada poderia estar acontecendo nestes dias com nosso vizinho, amigo, filhos. Um mundo ficcional de beleza trafega pela orla da Zona Sul carioca, por hotéis, pelas casas das famílias dos personagens. 
Boa parte deles mora no mesmo prédio e, muitas vezes, até no mesmo andar. O espaço social destes mundos não tende a privilegiar as situações de vida das camadas populares. Todas as três telenovelas de Manoel Carlos tiveram uma excelente aceitação do público e foram conduzidas pelo diretor-geral Ricardo Waddington. Todas elas também privilegiaram os acontecimentos em torno da personagem Helena e seus amores, família e amigos.

O escritor já mostrou alguns temas e situações de sua preferência, como a experiência amorosa de mulheres maduras, a maternidade, a prostituição de jovens, a violência, a questão racial. o alcoolismo, os ciúmes. Pode-se dizer, ainda, que Manoel Carlos tem um estilo de contar suas histórias: o naturalismo poético, classificação dada pelo próprio escritor. Pode-se observar a construção de situações e personagens o mais próximos possível do regime de organização espacial e temporal do cotidiano, poucas elipses e muitas cenas de conversação, seja nas saídas e entradas do elevador, nas mesas de jantar, nos carros em movimento, nas salas de estar, nos ambientes de trabalho. Os personagens tenderão a ser as principais instâncias narrativas. através dos diálogos das personagens a história será contada.

Um dos focos centrais diz respeito ao modo como cada personagem vai se sentir diante das situações de sua existência, ocorrendo uma forte ênfase na construção de uma compreensão psicológica dos motivos das personagens. Muitas conversas explicando o que aconteceu, o porque aconteceu, o que deveria ter acontecido, num contexto onde as ações parecem lentamente conduzidas ou até mesmo em suspenso, esperando o próximo discurso sobre o que deverá acontecer para que algo po isa de fato acontecer. As fortes emoções tenderão a conduzir a narrativa. muitos choros e muitas alegrias, sustos e sentimentos de aversão e raiva.

O amor na família, o amor pelos amigos, o amor pelo Brasil, o amorpaixão erótico são todos objeto de atenção especial de Manoel Carlos. Nos mundos possíveis que ele constrói esses tendem a ser os grandes temas das situações dramáticas. Em segundo plano as situações vinculadas ao trabalho. aos problemas econômicos, aos problemas políticos.

Mulheres apaixonadas foi, sem dúvida. um espaço de dramatização dessas temáticas a partir de moldes já estabelecidos e consagrados pelo gênero. Ocupou, todavia, o lugar das telenovelas que podiam experimentar também uma certa novidade narrativa. Foi. nessa medida, a expressão de um dos raros momentos onde personagens secundários tiveram suas situações dramáticas alçadas ao centro do palco, deixando protagonistas esperando alguns muitos capítulos para voltarem à cena.

Foi um interessante processo de criação que não será aqui explorado, mas que ajuda a entender a importância que tantas mulheres apaixonadas tiveram nesta telenovela, além de Helena, temos Lorena. Fernanda. Edwiges. Luciana, Heloísa, Hilda, Doris, Santana, Paula, Rafaela, Clara. Silvia. Marina, 
Laura, Vidinha, Raquel, Marcinha, Estela. Cada uma delas com uma intensa história de amor pra contar. Das dúvidas da virgem Edwiges à estratégia de Sílvia de ter por perto, sem culpa, o seu amante e a amante do seu amante; do amor de duas jovens de dezoito anos ao amor de Lorena por Expedito, ele bem mais jovem e pobre.

Todas elas trazendo, ao gosto de uma telenovela e ao gosto do Manoel Carlos, uma provocação para emocionar e para fazer pensar. Qual o modo de amar mais adequado para ser feliz hoje? O que devem fazer as mulheres e os homens com mais de quarenta anos? Quais os problemas mais usuais e por onde não se deve tentar resolvê-los?

Uma premissa que orientou a análise diz que a telenovela tem um modo próprio de organização e funcionamento, assim como as telenovelas de Manoel Carlos também os têm. Não se pode esquecer que se pode identificar uma marca própria na telenovela analisada, mas sem perder de vista o que ela traz de semelhante e regular com as outras telenovelas em geral e as outras de Manoel Carlos, em particular.

Isso para esclarecer que houve o cuidado de evitar a hiperinterpretação, $o$ ato de tecer afirmações que um olhar mais atento sobre a telenovela não permite verificar, validar. Buscamos perceber como determinado tema tem sido tratado na telenovela, não sendo o modo próprio de organização e funcionamento da telenovela o que se priorizou. Movimento pautado por um cuidado e respeito ao modo próprio de organização da telenovela, do cuidado de testar, de verificar se o que foi possível ler no texto audiovisual pode ser aprovado ou reprovado quando se examina a coerência do próprio texto.

A telenovela é um gênero ficcional constituído a partir da característica básica das séries - a tensão entre novidade e repetição, contando com telespectadores que desejam desfrutar da novidade da história, ao mesmo tempo em que se distraem seguindo um esquema narrativo constante, satisfazendo-se com o encontro de personagens, aventuras e soluções de problemas já conhecidos (Eco, 1991, p.123). Um telespectador de séries espera o retorno do idêntico, mesmo que mascarado, e gratifica-se com a sua capacidade de prever o desenrolar da história, saboreando assim a possibilidade efetiva do retorno daquilo que ele espera acontecer. $O$ telespectador, aqui pensado como leitor-modelo, usa a obra como um dispositivo semântico estrategicamente conduzido pelos realizadores responsáveis ${ }^{5}$. Isso tudo significa que para a elaboração desse gênero ficcional os realizadores devem saber construir a carpintaria do texto de tal forma que as expectativas dos seus telespectadores sejam atendidas.

Isso quer dizer que a representação do amor nas telenovelas passa, também, e principalmente, pelas características da obra, as quais fixam uma espécie de fronteira criativa, limites que demarcam as inovações e as exigências do que deve 
constar. Desse modo, supõe-se que o amor é representado a partir de regras já estabelecidas, as quais sofrem maiores ou menores mudanças, influenciadas pelas trajetórias dos realizadores e das histórias particulares dos campos específicos de produção e consumo das obras.

Apropriar-se de uma noção de gênero ficcional mostra-se adequada, pois ela permite compreender os formatos, as regras de funcionamento. a gramática, as estratégias de comunicabilidade usadas com o público, ou seja, uma série de elementos concernentes às exigências que a formulação de uma telenovela coloca para os seus realizadores. Borelli (1996) ajuda a compreender a telenovela como um gênero ficcional conformado por um conjunto de categorias classificatórias, historicamente demarcadas, que não devem funcionar como limites rígidos associados a exigências de padronização, e sim como guias e modelos de orientação que sofrem transmutações. Assim sendo, os "gêneros ditos originais" (epopéia, tragédia e comédia) funcionariam como pontos de partidas ou "matrizes de produção" das telenovelas sem, contudo, desconsiderar que, por diversas razões, estas matrizes sofreriam misturas, transformações, num movimento contínuo de "fluxo e redefinição" (ver também Lopes. 2002).

Por fim, as classificações demarcam referências comuns que funcionariam como estratégias de comunicabilidade dos realizadores com o público consumidor, na medida em que eles são capazes de reconhecer os gêneros, mesmo ignorando as suas regras de produção. gramática e funcionamento. Reconhecimento que se torna possível porque os gêneros acionam mecanismos de recomposição da memória e das representações sociais de diferentes grupos sociais (Borelli, 1996, p.76). Os estudos sobre telenovelas tendem a focalizar o melodrama e o folhetim como suas principais matrizes fundadoras, além das influências das radionovelas latino-americanas e do cinema norte-americano da griffe Hollywood (Ortiz et al., 1989: Pallottini, 1996; Martín-Barbero,1987 e Lopes. 2002).

Por fim, esclarecemos que a premissa que fundou a nossa leitura reza que o mundo possivel onde os conflitos amorosos existem nas telenovelas não será usado para demonstrar qualquer vínculo entre as ilusões construídas na narrativa e os dramas particulares dos telespectadores, seja para verificar o que se distingue da ilusão, seja para atestar o que se configura como real. Tal premissa demarca uma perspectiva interpretativa quanto aos efeitos possíveis desta experiência ilusória nos apreciadores, sem, contudo. autorizar qualquer inferência sobre as implicações subjetivas desta experiência para qualquer apreciador em particular.

\section{Amor e telenovelas}

Os escritores de telenovelas tendem a narram o amor associando-o a uma representação da sociedade brasileira. a um ideário de vida em comum. assim como procuram enredar o telespectador voltando-se para a sua 
intimidade, os dilemas e os prazeres que fazem parte do cotidiano dos sujeitos na contemporaneidade ${ }^{6}$. Abordam de modo ficcional o mundo externo ao telespectador, esperando que corresponda a sua demanda subjetiva, interna. Buscamos uma definição do amor romântico para esclarecer em que medida ele é considerado um mal-estar na atualidade, mal-estar narrado em prosa e verso nos meios massivos de comunicação. Para tanto, o estudo realizado por Costa (1999) foi o nosso guia.

Discordando de Costa, as telenovelas serão aqui tratadas não como "máquina reparadora de amores infelizes", mas como recurso reflexivo, ao nos aproximarmos das proposições de Giddens (1993). Ao tratar do desamparo dos sujeitos na atualidade este autor ofereceu uma chave analítica mais adequada quando permite reconhecer nas telenovelas, nos manuais de autoajuda etc. não apenas um modo de oferecer respostas orquestradas com o único fim de reparar amores infelizes, mas para colaborar na formulação deste ideário amoroso necessário para o aprocesso de construção de autoidentidade dos indivíduos.

Nessa medida, acredita-se que também as telenovelas tratam do mito do amor romântico e das exigências emocionais experimentadas pelos sujeitos na conquista da felicidade. As telenovelas são, desse modo, mais do que um receituário contra as dores de amor, elas são também uma expressão das muitas "estratégias argumentativas para dizer o que somos ou devemos ser em matéria de amor" (Costa, 1999, p.132).

$176 \quad 0$ panorama formulado por Costa sobre as principais estratégias argumentativas ou gramáticas do amor romântico na atualidade permitiu elaborar, a partir dos aspectos que têm sido explorados por estas vertentes, três vetores de observação das representações do amor romântico nas telenovelas. $O$ primeiro deles examina as definições amorosas presentes e a relação destas definições com as trajetórias dos personagens, a dinâmica dos conflitos narrados. Ao fazê-lo, a atenção esteve voltada para as soluções encontradas, pois elas ajudam a compreender as teses sobre o amor, em especial aquelas que dizem respeito ao ideal de felicidade.

O segundo vetor de observação dirigiu-se para estas definições sobre o amor, buscando examinar a dimensão racional ou irracional do amor, o lugar dos sentimentos nas situações vividas pelos personagens. As sensações e emoções associadas à paixão diriam respeito a quais crenças e julgamentos?

Por fim, o terceiro vetor de observação era o poder que o personagem apaixonado, o sujeito da experiência amorosa tem neste contexto. $O$ estado amoroso remete o sujeito a uma experiência de liberdade ou de servidão? Indagação que levou ao exame das atitudes e ações dos personagens, procurando interpretar o papel da cognição, do conhecimento, da racionalidade, da liberdade e do poder de decisão na dinâmica dos conflitos amorosos. A crença amorosa é validada como virtude moral? O que se 
enfatiza na vida dos personagens, um amor ativo ou um amor patológico romântico? É oferecida alternativa aos problemas do amor-romântico modemo? Se algo falhou na experiência amorosa, quem é responsabilizado, o sujeito. as regras do jogo amoroso historicamente circunstanciado, ou ambos?

\section{O amor em Mulheres Apaixonadas}

Primeiro capítulo. Primeiros momentos. Sol e calor, três mulheres conversando e tratando do principal assunto deste enredo: o amor pelos homens, o amor por elas mesmas, o ideal de felicidade. Helena e suas duas irmãs, Hilda e Heloísa juntas em torno da mesa da sala de Helena mostram uma intimidade familiar, sem pai nem mãe, sem irmãos, sem passado. mas com um presente tecido pela solidariedade entre elas e por três núcleos familiares distintos que se entrelaçam.

Hilda tem um marido e uma jovem filha. Ela está feliz no casamento, satisfeita no trabalho e tem uma excelente relação com a filha. Ao longo da história cuidará de sua irmã Heloísa, aquela que sofre do mal dos ciúmes. e estará sempre presente na vida de Helena e precisará cuidar dela mesma, lutará contra o câncer de mama. Um final feliz para uma personagem caracterizada pela serenidade e satisfação, pela sabedoria na condução dos conflitos.

Heloísa não tem filhos e não os quer ter, é casada com um arquiteto "bonitão e charmoso" que faz muito sucesso entre as mulheres. Parece apaixonado pela mulher, assim como apaixonado pela sua própria beleza e pela condição de ser admirado e desejado por outras mulheres. Heloísa. uma mulher sem grandes atrativos físicos, sem envolvimento e dedicação com o trabalho, sofrerá de penoso ciúme do marido.

Outros personagens viverão situações semelhantes, mesmo que cada uma delas tenha algo de particular. A semelhança está no tipo de amor. aquele onde o ciúme está presente, a necessidade do controle do outro e a ausência de autonomia também. Raquel vive a perseguição e a violência impingida por Marcos; Marina com ciúmes de Rodrigo e depois de Expedito.

Algumas mães serão retratadas seguindo este padrão, a mãe controladora que inferniza a vida dos filhos: mães que vão interferir na vida amorosa dos filhos principal motor dos estados de infelicidade que precisaram enfrentar. A mãe de Clara, a jovem apaixonada por Rafaela é um bom exemplo. assim como Marta, a mãe de Cláudio, o menino rico que se apaixona perdidamente pela mocinha pobre, loura e virgem virtuosa.

Voltando ao núcleo básico da historia de Mulheres e de nossa análise. citemos Helena, irmã de Hilda e Heloísa, personagem central que se diz. insatisfeita com o casamento, querendo viver emoções mais fortes, intensas. Helena está casada naquele momento com Teo, músico profissional. com quem teria um filho pequeno, Lucas. Dois personagens fortes com seus segredos, que ao final da trama serão desvendados. 
Helena lutará pelo amor que precisa ser reconhecido por ela mesma como fundamental para sua felicidade. Precisará reconquistá-lo. Um amorpaixão que preza um ideal de amor baseado no julgamento, na autonomia, na escolha que implica em dificuldades e dor, mas que produz o melhor estado da alma. Implica numa mudança pessoal para poder ser vivido.

Como Helena, numa situação semelhante, teremos Luciana e Estela. Luciana amava o primo desde pequena e o primo a amava. A família era contra, o primo mulherengo, Luciana sensata e madura que investe em sua carreira profissional. Ambos se separam. Muitos anos se passam: com o tempo começam a julgar que este amor é especial, jamais viverão algo assim. Por fim, fazem a opção de viverem juntos, crentes que este é o caminho para serem felizes.

Estela e sua paixão de menina pelo Padre Pedro. O reencontro que a faz mudar de vida, conquistar o padre, que comovido e apaixonado larga a batina. Ambos mudarão suas vidas para viverem mais felizes e juntos. Todas as três personagens viverão um ideal de amor romântico que privilegia o erotismo, a cumplicidade, o respeito ao outro, a liberdade e a condução sábia e racional dos conflitos. Estela merece um destaque, pois ela representará o sujeito que através do amor-paixão pode tornar-se uma pessoa melhor, um humano menos egoísta e mais voltado para o bem público, para a ação social humanista.

Nesta trama o amor dos amigos e da família é valorizado como fonte 178 básica para enfrentar os perigos da vida atual nas grandes cidades, mas não apenas nelas. Santana enfrenta o alcoolismo, não tem filhos ou pais, sofria da solidão que não conseguiu superar após a morte do marido. Para superar este problema contou com o apoio dos dos amigos, dos alunos, dos colegas de trabalho e depois do homem que cumpriu a função de amigo, protetor e amante. Santana se tratará e será feliz, consciente do limite eterno da "doença".

Raquel também enfrenta o medo paralizante; sem pais ou irmãos, contará apenas com a fiel Yvone, empregada doméstica também amiga-irmã, idealização das relações de trabalho entre o patrão e a serviçal. Um mundo mais fraterno e sem tantas diferenças sociais. Mas, o caso da personagem Raquel é outro que explora a importância dos amigos, da solidariedade dos colegas de trabalho e da presença edificante de um outro que de fato a ame, como possibilidade de enfrentamento das situações constantes e regulares que a fazem sofrer.

A familia constituída por pai, mãe e filhos é também um personagem consagrado pelo amor. Três núcleos familiares serão tratados como tal. $O$ núcleo da personagem Doris, aquela que maltrata os avós e que quer ascender socialmente a qualquer custo. Neste caso o lugar do pai na educação dos filhos e nos erros que pode cometer, remetendo a idéia de que ainda resta aos pais um poder sobre a educação moral dos filhos. No último capítulo, depois 
de bater na filha e de arrastá-la de volta pra casa, anuncia aos prantos que "eu errei como pai" e que ainda acreditava, que mesmo assim, tinha algo para fazer por sua filha.

O outro núcleo familiar exemplar é o chefiado por Lorena. Mulher mais madura que preserva a beleza, o encanto da sedução, o controle sobre os filhos. Autonomia, sensatez e sabedoria marcarão esta personagem que assume o amor por homem bem mais jovem e pobre. Personagem que parece ser uma das responsáveis pela defesa de um modo de amar mais maduro, onde a paixão existe sem perder a racionalidade e a capacidade de julgamento. A boa relação que estabelece com o ex-marido demonstra mais uma vez como os novos rearranjos afetivos contemporâneos podem ser criativos e produzir felicidade.

\section{amor romântico e a felicidade em Mulheres Apaixonadas}

Descrever, para lembrar, do que se sucede numa telenovela nem de longe representa as emoções criadas nos apreciadores a cada capítulo e muito menos todas as situações dramáticas vividas pelos personagens. Não podemos esquecer que temos uma longa história que se desenrolou por mais de seis meses, diariamente. Por isso, é visível a pobreza desta breve indicação dos dramas representados. O que se espera é que estas ligeiras indicações ajudem a rememorar e a esclarecer de que experiência amorosa se está tratando, sem deixar de respeitar o enredo, os modos de contar a historia.

Nesta telenovela, o amor amigo, o amor familiar, o amor-paixão são narrados como experiências centrais na vida dos personagens, enfatizando que não poderiam viver fora de um regime amoroso. Sem dúvida, esta experiência narrada toca nos modos de se enfrentar o desamparo ou vazio constitutivo, e de lidar com os sofrimentos imanentes ao existir humano e às condições econômicas, culturais e políticas em que vivemos.

Manoel Carlos parece defender a tese de que não existe felicidade sem amor. Amor demais, todavia, atrapalhará no estado de felicidade. Defende ainda que não existe país bom pra se viver, sem fome, sem violência, sem preconceito se o amor ao outro não puder mover os atos individuais. Neste caso, o autor valoriza o lugar da escola e da família, explorando as mais diferentes configurações. Quando os personagens não estavam inseridos num núcleo familiar, as redes de solidariedade dos ambientes de trabalho e das instituições de formação foram exploradas com destaque, valorizadas como experiências essências na vida contemporânea.

A família foi privilegiada, mas não foi apontada como exclusiva instância de amparo, solidariedade e formação da moral e dos costumes. As redes de solidariedade dos amigos íntimos, estas sim foram destacadas como se devessem ser uma das bases essenciais da formação dos laços sociais na 
atualidade. Redes que teriam a obrigação de oferecer e regular as regras e os modos de aprendizagem do amor solidário, do amor não individualista, do amor regido por códigos morais.

Ao fazê-lo, Manoel Carlos conduz a reflexão sobre a importância hoje das relações de amizade, de solidariedade. Positivas experiências do amor, capazes de gerar uma relação dinâmica e aberta, recriadora de novos códigos morais. $O$ amor-paixão romântico foi o centro da concepção amorosa narrada na telenovela examinada. $\mathrm{O}$ amor paixão foi caracterizado pela intensidade emocional, pela crença na escolha da pessoa especial, pela possibilidade dela ser conquistada e de com ela se poder compartilhar com cumplicidade, parceria, igualdade e liberdade uma vida em comum. Sexo e amor caminharam juntos e também separados. Mas, o verdadeiro amor foi construído tendo em vista uma vigorosa experiência sexual: $\mathrm{O}$ tratamento dado ao cuidado com os filhos remetia a criação de experiências familiares renovadas que não perdessem de vista a responsabilidade com os filhos e a responsabilidade social.

Por outro lado, uma série de situações vividas pelos personagens demonstra que não basta apenas se sentir amada e amar, o processo de conquista é penoso e difícil exigindo soluções racionais. Nessa medida, não se deveria perder de vista a capacidade de reinventar as novas formas de amar, como bem apresenta a situação de Helena, de Lorena, de Sílvia, de Clara e Rafaela e de tantas outras.

180 Podemos pensar que as situações narradas incentivavam, inclusive, a busca de solucões para os problemas amorosos que tivessem como orientação o particular de cada situação vivida pelos indivíduos. O caso de Silvia, que rompe com o casamento e organiza sua vida economicamente estável; tendo ao seu dispor o amante da empregada, no início da trama taxista e ao final chofer de Silvia. Empregada, sempre preservada da informação que dividia o amante com a patroa, torna-se governanta da patroa ao final da trama, numa suposta sólida relação de cumplicidade com Sílvia; muito feliz com o arranjo que estabelecera para sua vida. Sem dúvida, um modo pouco usual de lidar com as situaçoes amorosas, mas tratado na trama como um final possível e até recomendável. Lorena, o amor da maturidade, um outro exemplo das mulheres que podem namorar homens mais jovens sem perder a sabedoria que thes é peculiar, pois como disse o pretendente de Lorena no último capítulo: "as mulheres mais jovens são muito cansativas".

Enfim o amor-paixão valorizado foi aquele caracterizado pela liberdade de escolha, que tem uma dimensão idealizada, mas deve ter a clareza dos problemas que acompanham estas escolhas. A disposição para recriar novos modos de amar sem perder a ternura, a preocupação social e política, os compromissos com o outro. Para enfrentar o desamparo, o vazio, precisamos amar, mas precisamos aprender o melhor modo de amor. 
Quando isso não ocorre, as trajetórias das personagens indicam a dor de Heloisa, a morte de Marcos, as humilhações de Doris.

Situações dramáticas que mostram como as personagens de Mulheres Apaixonadas vi i.iam o mal-estar da atualidade, fazendo do amor em geral, do amor paixão em particular, experiências vitais para recriarem novas técnicas de viver promotoras da felicidade. Como esperava Freud, que promovessem a felicidade, apostando que "não existe uma regra de ouro que se aplique a todos: todo homem tem de descobrir por si mesmo de que modo específico pode ser salvo" (1930, p.33).

Nas outras telenovelas de Manoel Carlos. como se apresentam as situaçoes amorosas das personagens? Os outros autores de telenovelas brasileiras, por onde trafegam seus personagens na busca da felicidade amorosa? Em que medida o amor narado nas telenovelas brasileiras pode ser um fértil campo de pesquisa das marcas de autoria dos escritores-autores? Este artigo aposta nesta possibilidade e espera que novas pesquisas prosperem nesta área que reune mais de trinta anos de telenovelas de não menos trinta escritores-autores reconhecidos e permanentes artesãos que alimentam o imaginário amoroso na sociedade brasileira contemporânea.

\section{Notas}

${ }^{1}$ Apreciador é concebido neste ensaio como o sujeito que assiste telenovelas. Vive neste momento uma experiência lúdica geradora de sentimentos, sensações, reflexões. Ele é capaz de apreciar. emitir opiniões, julgamento sobre os efeitos emocionais, estéticos e comunicacionais (de sentido) que a telenovela nele provocou

2 Para maior clareza quanto a interferência reguladora do sistema de produção nas telenovelas e no sistema de apreciação. basta lembrar a ordem dos escritores de telenovelas exibidas depois do Jornal Nacional nos anos noventa. Em março de 1993 estreava Renascer, escrita por

Benedito Ruy Barbosa e Luiz Fernando Carvalho. Os dois surgiram neste horário, nestas posições, pela primeira vez. Em seguida. entrou em cena Fera Ferida (1993) de Aguinaldo Silva, com Denis Carvalho, na direção geral. Gilberto Braga foi o escritor seguinte, com a telenovela

Pátria Minha (1994). também dirigida por Denis Carvalho. Nesta ocasião, Braga, juntamente com a equipe responsável, enfrentou um cordel de problemas com esta telenovela que. por mestre das letras que é. soube, dentro do possivel, resolver. Silva e Barbosa retornaram várias vezes a este horário. Braga se ausentou por quase uma década. Neste período. ele escreveu minisséries e uma telenovela no horário das seis. Convém mencionar que dos anos oitenta até aquele momento, meados dos anos noventa. Silva e Braga foram os escritores mais frequientes deste horário. Muitos anos depois. nos 
meses finais de 2003, o telespectador verá uma nova reedição desta regularidade: Celebridades de Gilberto Braga estreou em outubro de 2003, seguida por A senhora do Destino escrita por Aguinaldo Silva em 2004. Estes dados mostram que Gilberto Braga e Aguinaldo Silva têm sido a mais de vinte anos um dos principais escritores das telenovelas do horário mais importante da Tv Globo, e que por mais de uma vez, as telenovelas que escreveram foram exibidas uma após a outra.

${ }^{3}$ Um olhar retrospectivo sobre este tipo de organização concernente às telenovelas exibidas no horário que sucede o Jornal Nacional, mostra, por exemplo, que desde o início dos anos oitenta firma-se um tipo de decisão sobre o escritor e o diretor geral que apresenta uma regularidade cuidadosamente orquestrada, provavelmente apoiada num conjunto de variáveis definidas tendo em vista um leque de dados que conjugam desde os índices de audiência conquistados, as hipóteses sobre as expectativas do telespectador quanto aos temas, as estratégias narrativas, o elenco, até as avaliações quanto às estratégias da concorrência e as preferências dos anunciantes.

${ }^{4}$ Manoel Carlos escreveu Sol de Verão em 1982/3 (20h). Retorna em 1992 para a TV Globo, escrevendo Felicidade (18h) e História de amor (18h), esta em 1995/6. A minissérie Presença de Anita (22h) foi escrita em 2001.

${ }^{5}$ Essa afirmação não nega a existência de outros 'tipos' de telespectadores que avaliam a obra como produto estético, sendo capazes de posturas mais 182 críticas frente as estratégias acionadas pelo texto, sem contudo se abandonarem à fruição das mesmas. Cada texto, enfatiza Eco (1986 e 1994), privilegiaria um ou outro leitor, oferecendo desafios que poderiam não só pôr à prova sua competência textual, como também aprimorá-la.

${ }^{6}$ Vale lembrar que estes escritores precisam do público para existir, sendo obrigados a oferecer para os telespectadores um mundo ficcional que vá ao encontro do que desejam. Assim como fica evidente que os milhões de telespectadores de telenovelas esperam que este encontro entre o que é oferecido e aquilo que se deseja se realize.

\section{Referências}

ALENCAR, Mauro. A Hollywood brasileira. Panorama da telenovela no Brasil. Rio de Janeiro: Senac-Rio, 2002.

BAUMAN, Zygmunt. O mal-estar da pós-modernidade. Rio de Janeiro: Jorge Zahar ed., 1998.

Amor líquido. Rio de Janeiro: Jorge Zahar, 2004.

BORELLI, Silvia Helena Simões. Ação Suspense, emoção: Literatura e cultura de massa no Brasil. São Paulo: EDUC/Estação Liberdade, 1996. 
BOURDIEU, Pierre. Razões práticas: Sobre a teoria da ação. Campinas, SP: Papirus, 1996. As regras da arte: gênese, estrutura e campo literário. São Paulo: Companhia das Letras, 1996 (a).

COSTA, Jurandir Freire. Sem Fraude nem favor. Estudos sobre o amor romântico. 4ed. Rio de Janeiro: Rocco, 1999.

COSTA, Maria Cristina. A milésima segunda noite. São Paulo: Annablume, 2000.

DICIONARIO da TV GLOBO. Programas de dramaturgia e entretenimento. Rio de Janeiro: Jorge Zahar, 2003.

ECO, Umberto. Lector in fabula. São Paulo: Perspectiva, 1986.

Fronteira, 1991.

Sobre os Espelhos e Outros Ensaios. Rio de Janeiro: Nova

Seis passeios pelos bosques da fícção. São Paulo: Companhia das Letras, 1994.

FREUD, Sigmund. O mal-estar na civilização (1930). Rio de Janeiro: Imago ed., 1997.

GIDDENS, Anthony. A transformação da intimidade. São Paulo: Unesp, 1993.

Modernidade e identidade pessoal. Oeiras: Celta Editora, 1994. GOMES, Wilson. "Estratégias de produção de encanto". Textos de cultura e comunicação, Salvador, n35, p99-124, 1996.

La poética del ciene y la cuestión del método en el

análisis fílmico. Significação. Sao Paulo, n21, junho 2004.

HAMBURGER, Ester. Diluindo Fronteiras: a televisão e as novelas no cotidiano In: NOVAIS, Fernando e SCHWARZ, Lílian (org.) História da vida privada no Brasil. São Paulo: Companhia das Letras, 1998.

LOPES, Maria Immacolata et al. Vivendo com a telenovela. São Paulo: Summus, 2002.

MARTÍN-BARBERO, Jesús. De los medios a las mediaciones. Comunicación, cultura y hegemonia. México: Gustavo Gilli, 1987.

ORTIZ, Renato; BORELLI, Silvia Helena Simões; RAMOS, José Mário Ortiz. Telenovela: história e produção. São Paulo: Brasiliense, 1989.

PALlOTTINI, Renata. Dramaturgia de Televisão. São Paulo: Editora Moderna, 1998.

SARLO, Beatriz. El Imperio de los Sentimientos. Buenos Aires: Catalogo Editora, 1985.

SIMOES, PAULA. Mulheres Apaixonadas e outras histórias: amor, telenovela e vida social, 2004. Dissertação de mestrado (Comunicação Social) - Universidade Federal de Minas Gerais.

SOUZA, Maria Carmem. Telenovela e representação social. Rio de Janeiro: e-papers, 2003. 
Autoria nas telenovelas: um método de análise. In: Souza, Maria Carmem (org.) Analisando telenovelas. Rio de Janeiro: e-papers, 2004.

Reconhecimento e consagração: premissas para análise da autoria das telenovelas. In: GOMES, Itania e SOUZA, Maria Carmem (org.) Media e cultura. Salvador: PosCom/UFBA, 2002. 